\title{
Viet Nam 1969/1970: Pacification as a Path to No-where
}

\author{
Gerald Waite \\ Ball State University, Muncie, Indiana, USA
}

\begin{abstract}
Refugees, their movements, and the problems associated with their survival and maintenance in combat scenarios are a constant problem in the search for peace in war zones. In the American conflict in Viet Nam, the traditional village structure with its communal character created the perfect situation for seminal revolutionary movements and the ensuing conflict. These same villages then became targets for search and destroy operations and later wholesale clearing operations in which entire populations were forced into resettlement. In Quang Nam Province, in Central coastal Viet Nam, over $50 \%$ of the population or 500,000 people were in refugee status by 1969 . The concept of "pacification" in 1970 focused on putting people back on the land in their original village areas or a return to normalcy for some of the population. This case study, by a former civil affairs officer, details movement of a population in refugee status to a "return to village" project, as pacification and an attempt at creating a manageable strategic population area. It failed on both counts. The mistakes inherent in this project illustrate some of the more widespread problems which plagued the conduct of the conflict in Viet Nam. It also calls into question, the concept of the military planning and execution of resettlement. The lack of a thorough understanding of local culture and subjects involved by planners and project officers alike contributed to a village which neither replaced the original nor survived as an improved model.
\end{abstract}

Keywords: Vietnam, Vietnam War, pacification, Vietnamization, refugees, resettlement

The Vietnamese wars of the last century, especially the French and American, can be more fully understood as the inevitable collision of economic systems and the corresponding evolution of revolutionary paradigms. Beginning with the Industrial Revolution of the 19th century and continuing to this day, economic systems have been manipulated and changed by an ever-expanding market-economy. Authors such as Scott (1976) and Wolf (1968) look at the broad scope of peasant revolution in Asian societies and create an analysis that indicates that moral based revolts of the peasantry of the world are the inevitable outcome of resistance to the forces of globalization. In "The Great Transformation", Karl Polanyi (1944) claimed market expansion and the organization of production in the development of the "self regulating market" produces great evils and if left unchecked would be detrimental to society. He goes on to write that primitive subsistence societies are organized in ways that do not permit hunger and as such are more humane than more advanced societies and that the only means to assimilate people from these groups into the market economy is through the introduction of starvation. Polanyi (1944) also referred to counter-movements which he terms as "interventionism" or forces that checked the action of the free-market "in respect to the factors of production, labor and land" (p. 131). The author suggests that these counter-movements surfaced in Southeast Asia in the form of rebellions centered

Gerald Waite, M.S. in Anthropology, Lecturer Emeritus, Research Fellow, Center for Peace and Conflict Studies, Ball State University, Muncie, Indiana, USA. 
around colonialism and the creation of a peasant subsistence crisis.

The colonial state with its ever increasing demands upon the peasantry; the transfer of traditional communal-use lands from village to state, with the loss of the subsistence use of those lands; the rise of a landlord class as opposed to the earlier "patron" model; and the increased emphasis on the cash economy in every sector of peasant life, effectively demolished the reciprocity based nature of the communal Vietnamese village and created the moral outrage necessary for revolution (Scott, 1976). ${ }^{1}$ These conditions coupled with an insider/outsider consciousness on the part of the peasantry and the rise of nationalism at a state level, fueled cooperative rebellion against the French colonials, and then their replacements, the Americans.

James Trullinger (1980) estimated that as many as $80 \%$ of the population My Thuy Phuong, a village lying just South of Hue the ancient Imperial capital, supported the Viet Minh and later the Viet Cong (VC). As soldiers in Vietnam, we were told of American military estimates ranging from $75 \%$ to $90 \%$ loyalty to the Government of South Vietnam $(\mathrm{GVN}){ }^{2}$ Villages that were urban in their proximity to larger population bases, such as Saigon, Hue, or Danang were more likely to be considered as friendly to the GVN and suffered much less long-term damage to their traditional infrastructure. Trullinger's (1980) study of My Thuy Phong and Schell's (1968) of a village named Ben Suc, about 30 miles from the city of Saigon, ${ }^{3}$ show the opposite extremes of village survival. My Thuy Phong survived the war intact even though it had a deep allegiance to the revolutionary front and few ties to the central government probably because it was close to Hue, on a railroad and Highway 1, the only fully operational highway during most of the conflict (Trullinger, 1980). The village Ben Suc, on the other hand, was completely destroyed and its inhabitants all moved or detained because it was deeply rural and seen as uncontrollable. To use Jonathon Schell's own words: "As though, having once decided to destroy it, we were now bent on annihilating every possible indication that the village of Ben Suc ever existed" (1968, p. 132). The author of this article observed that those villages close to Highway 1 survived almost unscathed, while those removed even a short distance from the road could be termed a no-man's land and a free-fire zone. What follows is an account of one of the latter case villages.

\section{Time and Place}

Vietnam was divided into four sectors of military control during the American War. The northern-most sector was that from Quang Tri, or at the demilitarized zone, south to a town called Tam Ky. This area was designated "I Corps" and included the Imperial Capital Hue, and the autonomous city of Danang. During the year of 1970, this author was a first lieutenant assigned to the 29th Civil Affairs Company in Danang. Civil Affairs (CA) is that branch of the Army which deals with the problems associated with civilians in military areas of operations. Every military unit of battalion size or larger size has what is termed a S5 or G5 office charged with the responsibility of managing civilians and assisting with problems of civil control and subsistence in military operations. The 29th Civil Affairs Company had the responsibility of providing CA trained officers and enlisted men to all the operational (infantry) units in I Corps. As such, this author was subsequently assigned to the First Marine Division G5 Office at Freedom Hill near Danang. During that tenure,

\footnotetext{
1 James Scott coined the phrase "Moral Economy of the Peasant" in his book of the same title however, other authors such Gerald Cannon Hickey (1993), and Jonathon Schell (1968) address the ideas of exploitation, and their results in the Vietnam experience.

${ }^{2}$ Figures for loyalty to the GVN and American cause were very high. "Tour 365" was the name of an American military produced tour book for servicemen like myself and their families that stated $95 \%$. The figures given were obviously optimistic but none of us dared to think they could be that terribly inaccurate.

${ }^{3}$ Saigon was the name of the capitol of South Vietnam. It is now known as Ho Chi Minh City.
} 
he was assigned to a variety of projects in the 1st Marine Area of Operations (AO) often, as an advisor to various units in the field. Most duties pertained to the movement of refugees and their medical and subsistence needs. Beginning in June of 1970, that assignment shifted to a project entitled the Go Noi Island Resettlement in which 1st Marine division wanted to move several thousand refugees from various camps in their AO to a previously occupied inland island called Phu Ky or Go Noi.

Go Noi Island is an area of about 2,500 hectares completely surrounded by rivers, $25 \mathrm{~km}$ south of the City of Danang, approximately in the middle of Quang Nam Province. Prior to 1965, it was one of the richest areas in the central part of Vietnam. Primary sources of income were from raw silk production and rice agriculture (Waite, 1970a). Between 1965 and 1968, Go Noi was an area hostile to the GVN and American forces in Vietnam. Marines in Quang Nam Province nicknamed it "Dodge City", an indication of its growing reputation as a place of firefights and casualties (Gregg \& Waite, 1970). ${ }^{4}$ The island lies in Dien Ban District, which was labeled as the most contested area of I Corps (Hunt, 1995). The first major operation against the VC infrastructure entitled Operation Meade River, took place in November 1968, as part of an Accelerated Pacification Program. This operation manned with Marines, soldiers from the Army of the Republic of Vietnam $(\mathrm{ARVN})$, and national police, cordoned the area, interrogated the residents, and detained those who were deemed possible guerillas. The rest were allowed to go home. The operation did not succeed in actually securing the area, however, and by June of 1969, several major US Marine operations were directed at Go Noi with the aim of depriving the VC and North Vietnamese Army (NVA) of its use. These multiple operations mounted against the fortified villages of the island had little effect upon the deteriorating security situation (Hunt, 1995).

Go Noi is actually quite close to Highway 1 and just a few kilometers from the provincial capital of that time, Hoi An. It was connected to the surrounding land areas by two railroad bridges through the approximate center of the island and a bridge, called "Liberty Bridge" by the Marines, at the west end of the island connecting to a village called An Hoa and the Marine firebase located nearby. Highway 1 passed about $1 \mathrm{~km}$ from the eastern-most tip of the island, and the easiest access from there was by canoe or sanpan. Even though access sounds easy, it was not, and the island was remote and deeply rural, as it still is today. One Marine who was involved in an operation called "Pipestone Canyon" on the island said they were told it was a rest and relaxation ( $\mathrm{R} \& \mathrm{R}$ ) center for the NVA and VC (http://usmcwife.hypermart.net/gonoiisland.htm). That operation did find regular units of the NVA on the island and encountered stiff resistance from those units as well as the VC. The tactical situation of Quang Nam Province in 1969 required that such a large-scale staging area for revolutionary forces be dealt with, or as the strategists would say, "the enemy should be deprived of the use of that real-estate". Go Noi was less than $5 \mathrm{~km}$ from the District Headquarters of Dien Ban, about the same distance from the provincial capital in Hoi An and the 5th Marines Headquarters at An Hoa, $12 \mathrm{~km}$ from 7th Marines at Fire Base Ross near Que Son, and within $122 \mathrm{~km}$ rocket range of the large US airfield at Danang. This proximity allowed the VC and NVA almost unlimited access to those targets. The island had a pre 1965 population of about 17,500 people in 12 or more autonomous villages spread out over the island's $11 \mathrm{~km}$ east to west and averaging $3 \mathrm{~km}$ in width north to south. These villages were then further dispersed into hamlets ranging in size from a few houses to a few dozen houses (http://www.marzone.com/maps/Map_6640.htm). ${ }^{5}$

\footnotetext{
${ }^{4}$ I am the sole author of the Go Noi After-Action Report. It is, however, signed by my commanding officer Werner Gregg so references to it will include his name.

5 These are my recollections coupled with 1965 maps available on the Internet.
} 
Many of the people the author talked to who had originally come from the island said that people there were quite prosperous and well established with many brick and masonry homes. Even though the author was never physically on the island before it was cleared, the brick and mortar fragments left from the bombing would seem to bear this out (Simonson, 2008).

In June 1969, The GVN and allied forces of Quang Nam Province decided to clear the population from Go Noi and render the island useless to the opposition forces. Leaflet drops were conducted informing the people that the area would be bombed and that they should leave. By July 1969, Go Noi was cleared of its original inhabitants (Personal Communication, 2002). Artillery shelling and bombings, including many B-52 "arc-light" missions, reduced the island to pulverized dust resembling a moonscape devoid of flora and fauna.

\section{Resettlement}

In April 1970, I Corps command and the GVN created a return to village project on Go Noi Island as a joint project. First Marine Division was tasked with road building, engineer support, and civil affairs assistance for the project. This author went to live on the island June 17, 1970, as the civil affairs officer. First Marine Division had assigned a Marine engineer officer to the project, and the province chief had assigned a South Vietnamese captain as the officer in charge of the project. There was also a civilian from the Agency for International Development and its subsidiary Civil Operations and Rural Development Support (CORDS) (Fritz, 1997). Initial plans called for the resettlement of 17,000 refugees on the island. This was approximately the number of people dislocated from that area and spread out in various refugee camps in Quang Nam Province.

Several facts became clear early on in this project that set the tone for later developments. Even though the GVN numbers were large on paper, the refugees that were allowed back on the island were small in number. The first hamlet, named Phu Loc, at the eastern-most point of the island was the only real focus of the project and could accommodate no more than 2,200 people at best. It may have achieved a population that large at some time during the project; however, most of the counts reflect a population of between 800 and 1,000 (Gregg \& Waite, 1970). Even though the GVN initiated the project, most of the materials and resources utilized were from 1st Marine Division and CORDS. The people who were moved back to the island had absolutely no resources, no money, no food, no implements, no seed, and little hope. Individuals were randomly picked from the refugee camps without regard to family affiliation or hamlet of origin, loaded in trucks and dumped in the area of Phu Loc. There was a village chief, appointed by the District Chief at Dien Ban however, in dealings with him, even though friendly and eager, he seemed to have no influence over anything connected with the village. Another villager said that he was a well to do farmer from another village near Dien Ban who had no connection to Phu Loc other than a political appointment from the district chief. Most of the people in Phu Loc early on seemed to have little connection to the island. The project personnel tried to get people to help mark pre-war gravesites so that roads could be plotted around them, but no-one knew of any. Several were discovered as the area was mapped for roads and access to the village and the assumption at that time was that the people of Phu Loc came from a different part of the island.

The need for security surpassed all other requirements in the construction of hamlets. Rather than the traditional hamlet structure spread out in the fields, Phu Loc and later, a second village named Phu Phong, were ordered on straight-line rows of houses that permitted open shooting lanes (fields of fire) between houses, specific straight line boundaries that allowed easy visual access to the comings and goings of people in the 
hamlet, and in the large expanses surrounding the hamlet cleared of any vegetation. The settlements took on the appearance of the "Strategic Hamlets" of the Diem/Nhu era of the late 50's (Hunt, 1995). These become fortified hamlets of a different nature than the earlier island villages. The fortified villages before the island was cleared included bunkers to protect the inhabitants against air and artillery attack. Many houses had bunkers for the household and another bunker for the animals. Later, many of these houses were connected to tunnels that were used by the revolutionary front. Carl Fritz (1997) noted in his online article about Go Noi that these tunnels were actually lined with American cement. After the return, the villagers had bunkers as part of their houses, but the village was considered fortified in that it had concertina wire around it, trip flares and claymores in an outer perimeter, cleared fields of fire in every direction, and a heavily armed security contingent highly visible at all times.

This was the era known as pacification for which the principle metaphor was "winning the hearts and minds" (Hunt, 1995; Fritz, 1997). However, the real deal obviously could be seen in the number of people carrying weapons. Phu Loc had security provided by a US Army Military Advisory Team (MAT) of six men and an accompanying Regional Force (RF) and Popular Force (PF) company of over 100, a Marine Combined Action Platoon (CAP) of seven with a People's Self Defense Force (PSDF) of 40 or so armed teenagers, a detached Korean Marine company of 200, and various military types like the author, the Marine engineer, and the South Vietnamese project officer. Many times in the five months living on the island, there were more people carrying guns than hoes. In his foreign service reminiscences, Fritz (1997) stated that "one night the VC came... old men, women, and children, armed with shotguns and grenades, met them at the perimeter of the hamlet and drove them off" (p. 1). Anyone who ever lived in these villages knows that old men, women, and children were not armed with anything other than an occasional pitchfork that had not been taken from them. On the night in question, the regular military forces did most of the fighting, the Vietnamese captain got wounded, med-evaced, and never came back to the island, The PSDF with their Thompson sub-machine guns and other World War II arms disappeared in the night.

Clearing the island for habitation and farming was actually a bigger job than we first expected. The entire ground surface was pockmarked with thousands of bomb craters. There was unexploded ordinance everywhere, which had to be found and cleared before bulldozers could be brought over and used. Even though ground was eventually cleared and leveled for growing, very few people had the resources to plant anything, and to this day, it is unknown if the government ever redistributed any land to the people who moved to the island. It may have stayed in the hands of the District Chief of Dien Ban or some of his friends. First Marine Division donated irrigation pumps to the village, but no one tried planting any rice in the first year during which time the pumps disappeared.

The second village of Phu Phong was started on the 10th of July $2 \mathrm{~km}$ west of the first village, but no land was cleared other than for the village proper. No more than a hundred people ever tried to live there. Security was not as good as the first village and the CORDS project officer was killed by a landmine in August, a death which effectively terminated most of the building efforts. ${ }^{6}$ An announced visit by South Vietnamese President Thieu to Phu Loc focused most of the attention on that village at the expense of Phu Phong. During the month prior to that visit roads were surfaced, a school was built, flag poles erected, wells dug, and some fields were

\footnotetext{
${ }^{6}$ My own brother-in-law, an Army pilot, told me that his squadron had destroyed the second village six months after I left Vietnam because he had taken fire from it when flying over.
} 
planted in vegetable crops although August was not necessarily a good month for planting anything. Funds were located to purchase books for the school and it was in use during Thieu's visit, but shortly thereafter, it became a storage building for the district chief's rice. There were 1,838 people living on the island during Thieu's visit but never that many people after that time (Gregg \& Waite, 1970). ${ }^{7}$

In late 1970, the Hamlet of Phu Loc became a model for everyone who wanted to dabble in the construction of resettlement hamlets. During the project and after the initial phase, which ended in October, the project had daily helicopter visits from dignitaries and high-ranking military officers from all the services represented. The only missing notable was the district chief of Dien Ban, and the project team assumed he wanted to avoid us so that he did not have to sign the requisition for the five gallons of petrol he allowed the project each day. The positive side of this was that materials were readily obtainable just for the asking during the early stages of the project. The down side was that we spent far more time escorting dignitaries around our "human zoo" as we called it, than we did actually doing real work.

No one at the site or in the government really put much thought into how people were going to live or where food would come from. The Marines donated ship dunnage from the harbor in Danang and a Marine engineer sawmill. The sawmill was used to cut lumber for the housing and sold it for $\$ 2,500 \mathrm{Vn}$. or about $\$ 21.50$ American for enough lumber to build a one room house. Since none of the villagers had any money, the project officers set up village work crews with Marine and Province supplied funds where people could work enough to get food and get the money to buy a house kit. People worked in the sawmill, and the only non-Viet was a Marine who operated the saw itself. People worked in the village, helping construct houses and digging wells. Much of the heavy work such as the construction of a "non-standard bridge", roadways, and field clearing were done by the Marines (Gregg \& Waite, 1970). ${ }^{8}$ As a civil affairs officer, the author set up an unexploded ordinance disposal program with money given by the Marines. It employed children of all ages to find unexploded bombs and ordinance of all types which were then blown up in place. The kids were paid piece rate with higher prices paid for larger bulldozer damaging bombs. This in turn generated another source of income for many of the families in the hamlet and often some food, too. On days when we had some C-4 left, it was used to stun fish in the many small ponds created by craters thus giving the kids some bonus protein to take home (Waite, 1971b).

\section{Aftermath}

Go Noi Island was in many ways a model for resettlement. It was one of the first to move a large number of people from refugee camps back to the land. It created home ownership once again for people who had been deprived of their homes, and it created some land usage if not land ownership. The people who wound up living in Phu Loc still have family there and at this point have land tenure. Phu Phong was not successful, in part because of distance from the roads and because it did not get the flow of resources the first hamlet did. It does exist now, under a different name, although the author does not know the specific history of its rebirth. American forces departed Quang Nam in 1972 and with that, Go Noi was once again out of sight and out of mind.

Both hamlets lie in a flood plain, which has worsened in recent years because of environmental degradation from the indiscriminate use of defoliants during the war years. One of the noticeable changes at

\footnotetext{
7 The purpose of this paper is not to criticize or point out shortcomings of the various groups involved but it is impossible to tell the story without running into the inept comedy on the part of all of us who were involved in these projects.

${ }^{8}$ I have no idea why I called it a "non Standard bridge".
} 
this time is that Phu Loc (renamed Ap Troung) has assumed a shape more like that of the older pre 1965 hamlet. The Marine sawmill is still there but rusted solid from repeated soakings in the river. Many of the hamlet's dwellings are built up at higher than ground level and some of the lower concrete structures show water lines from previous floods. Several houses have boats tied to them. Vietnam has a large number of very broad short rivers that drain from the mountains the 20 or $30 \mathrm{~km}$ to the South China Sea. The Dien Binh River on the North side of Go Noi was one km wide and relatively deep in 1970. Now it is 2-3 km wide and shallow, with, average depth of 1 meter, and can rise 3-4 meters overnight. This floods all the low-lying areas like major parts of Go Noi often with loss of crops and sometimes loss of life. The Marine Bridge that was constructed in 1970 was washed out in 1997, and a new bridge opened late in 2002. During the intervening years, access to the island was by ferry or walking the two railroad bridges. A cursory inspection of the island and subsistence shows very little rice agriculture and a large reliance on melons, peppers, vegetables, and tea. This would indicate a move away from subsistence agriculture and an increased immersion in the market economy through the production of cash crops. Even though the island has yet to be electrified, there is an abundance of material goods, such as radios, walkmans, mopeds, and bicycles. People made the comment that they were glad to be a little removed from the government, but they did not look very removed from material culture.

\section{Conclusions}

The Go Noi Island resettlement project could indeed be called a success, not because it managed to put people's lives back together but because in fact it did not. Traditional economies in peasant societies, especially in Southeast Asia, are reciprocal economies with safety mechanisms built in to ensure survival of the group. The cash economy and market based insecurities are in direct opposition to peasant values of risk management and risk sharing, which are the basis for the traditional village structure (Scott, 1976). Revolution occurs when the traditional values are breached in such a way as to continually threaten subsistence. The colonial government of Vietnam did just that. The depth and breadth of that revolution is little understood by the Americans involved in it. They failed to understand that the revolution grew out of the peasantry itself rather than the commonly held paradigm where revolution is fomented by the upper classes or communist agitators and flows downhill to the working class. This concept alone may have been one of the important factors in the outcome of the war. We went to Vietnam secure in our belief that Ho Chi Minh was the sole cause of the revolution and that once the North was defeated all of the South would be compliant subjects of an Americanized capitalism. The idea that revolution could come from the peasant class and that the nationalism of the ruling class was in fact just the glue that held things together was beyond our scope and consequently a large part of our failure. Americans evaluated the situation and sized things up with the rhetoric of democracy, free market, trade, and most importantly security, never realizing that the most essential question was never asked: What did the people need and how were those needs met previously? People like Colonel Corson in Mary McCarthy's "Vietnam" looked at the peasant as someone who needs enough money to survive. To him (Corson), "the profit motive is the sole incentive capable of spurring anyone to productive effort" (McCarthy, 1967, p. 78). The context surrounding this statement may over-trivialize the importance of it. The idea of profit motive and incentive is the paradigm on which American capitalism is built and the creed of many ambitious Americans, of which a Marine Colonel would certainly be one. However, it is antithetical to a peasant's worldview.

Peasant economies and their accompanying mechanisms are deeply rooted to the land. The first order of business in market economy assimilation is separating village inhabitants from their native environs. No one 
closely involved in the war effort really understood what we were doing, but it could not have been done better with pre-planning. The search and destroy operations and the refugee movements of the war effectively denied the VC and NVA the use of real estate and just as effectively denied most of Vietnam's rural peasantry the same access. Polanyi (1944) wrote that separating man from the land is the first requirement of the market economy, and that in "modern colonization...the social and cultural system of the native must first be shattered" (p. 178). Americans repeated the 19th century process that had proven successful with Native American populations. Removal and resettlement to secured areas hence, refugee camps, and resettlement hamlets in place of the earlier reservation process, was deemed the answer to an uncontrollable security situation. However, enhanced security and manageable hamlets were not the only outcome.

Once peasants were removed from the land, many of the mechanisms that supported their reciprocal social organization were weakened but still present. The patrons and landlords were gone, no one in the camps had more wealth than anyone else, and land ownership in name only is a liability if it cannot be farmed. Kin structure still existed, but with resources being scarce in the camps, reciprocity was minimal. The final blow to peasant culture came in the form of an indiscriminate scattering of people back to the land. Kin were separated and neighborhoods no longer existed. The nuclear family was often dismantled because the men were detained as potential guerillas or drafted into the GVN armed forces. People in resettlement hamlets were a mix of people from all over and more strangers than an American sub-division. This put everyone at the mercy of the market economy. Without the protective mechanisms of the original village and the reciprocity structures therein, survival was dependant on the individual's ability to find a way to support him/herself and whatever dependants were with them. Crafts, cottage industry, vegetable farming, and wage labor where available, became the stock and trade of people who had once supported their families entirely in the mono-culture of rice.

The structural layout of the village was also urban and foreign. Even in resettlement, people were still separated from the land they had once lived on. The traditional layout in the area of Phu Loc was an elongated cluster of houses following a footpath north to south in close proximity to individual landholdings. The resettlement hamlet was laid out with only security in mind, and the cleared zone around the hamlet put vegetable gardens and other land based enterprise about $0.5 \mathrm{~km}$ from the people who might have worked the land. Because of this distance, people were reluctant to start gardens and rice.

Removal and resettlement then serve to limit revolt and to force peasant assimilation into the larger economy. Scott (1976) called this "passive adaptation" (p. 205). Strategic hamlets and resettlement projects only intended to address the revolt part of the equation. The idea of separating peasants from the land, limiting their connection to it, and forcing the resulting assimilation process, came as an unintended consequence of movement to a secure military outcome.

\section{References}

Brocheux, P. (1995). The Mekong Delta: Ecology, economy and revolution, 1860-1960. Journal of Political Ecology, 4(1), 12. Chaliand, G. (1969). The peasants of North Vietnam. Middlesex, England: Penguin Books Ltd.

Fritz, C. R. (1997). An American civilian in the Vietnam War. Retrieved from http://americandiplomacy.web.unc.edu/1997/10/an-american-civilian-in-the-vietnam-war/

Gregg, W. E., \& Waite, G. E. (1970). After action report, Go Noi Island Resettlement Project. Document Number AVII-CA-3, Department of the Army, 29th Civil Affairs Company.

Hays, G. (2002). Civic action a true story: Marines fighting a different war in Vietnam. Lexington, Kentucky: Ronald E. Hays. Hickey, G. C. (1964). Village in Vietnam. Forge Village, Massachusetts: Yale University Press. 
Hickey, G. C. (1993). Shattered worlds: Adaptation and survival among Vietnam's highland people during the Vietnam War. Philadelphia: University of Pennsylvania Press.

Hunt, R. A. (1995). Pacification: The American struggle for Vietnam's hearts and minds. Oxford, UK: Westview Press. Jamieson, N. L. (1995). Understanding Vietnam. Berkeley and Los Angeles, California: University of California Press. McCarthy, M. (1967). Vietnam. New York: Harcourt, Brace \& World Inc.

Polanyi, K. (1944). The great transformation. New York, Toronto: Farrer \& Rinehart Inc.

Schell, J. (1968). The village of Ben Suc. New York: Vintage Books.

Scott, J. C. (1976). The moral economy of the peasant. New Haven, London: Yale University Press.

Simonson, R. (2008). Every Marine: 1968 Vietnam, a battle for Go Noi Island. Westminster, Maryland: Heritage Books.

Trullinger, J. W. (1980). Village at war: An account of revolution in Vietnam. New York, London: Longman.

Waite, G. E. (1970a). Go Noi Island information report. Department of the Army, 29th Civil Affairs Company.

Waite, G. E. (1970b). Go Noi Island report. Department of the Army, 29th Civil Affairs Company.

Waite, G. E. (1971a). Critique of Opord 1. Department of the Army, 29th Civil Affairs Company.

Waite, G. E. (1971b). Ordinance collection program for land-clearing projects. Department of the Army, 29th Civil Affairs Company.

Wolf, E. R. (1968). Peasant wars of the twentieth century. New York: Harper and Row Publishers. 